\title{
In situ hybridisation in formalin fixed, paraffin wax embedded liver specimens: method for detecting human and viral DNA using biotinylated probes
}

\author{
N V NAOUMOV, G J M ALEXANDER, A L W F EDDLESTON, R WILlIAMS The Liver \\ Unit, King's College School of Medicine and Dentistry, London
}

SUMMARY A rapid and reproducible technique for in situ hybridisation, using biotin labelled probes for the Y chromosome, human DNA, hepatitis B virus DNA and cytomegalovirus DNA on formalin fixed, paraffin embedded liver tissue, was developed. The degree of proteolytic digestion of tissue specimens is critical to ensure adequate unmasking of DNA and to avoid non-specific staining, a consequence of endogenous biotin in liver. Specific in situ hybridisation was achieved after digestion with pepsin, proteinase $\mathrm{K}$, or protease, which gave optimal results. Both hepatitis B virus DNA and cytomegalovirus DNA were visualised in tissue from patients with chronic hepatitis B virus infection or in liver transplant recipients, respectively; the distribution of viral DNA was shown to be quite distinct between the two groups of patients.

In situ hybridisation has proved an invaluable tool in the localisation of specific nucleic acid sequences in cell suspensions or tissue sections. The technique is based on the formation of a highly specific hybrid between an appropriately labelled probe of nucleic acid and its complementary sequence in the specimen. The presence of both human nucleic acid sequences and viral DNA has been shown in formalin fixed, paraffin wax embedded tissues using radiolabelled probes. ${ }^{1-3}$ More recently, probes with a biotin-avidin detection system have attracted interest; the advantages of this system include rapid detection, improved microscopic resolution, prolonged storage without decay, a wide range of applicability and avoidance of a radiation hazard. In situ hybridisation using biotin labelled probes has been used successfully to identify both normal cellcular and viral DNA sequences in formalin fixed paraffin embedded lung, tonsil, and brain tissue. ${ }^{4-6}$ We describe the development of a rapid and reproducible method for in situ hybridisation in formalin flxed, paraffin embedded liver tissue with a variety of biotin labelled probes.

\section{Material and methods}

Liver tissue was obtained from patients with known chronic $\mathrm{HBs} \mathrm{Ag}, \mathrm{HBeAg}$ positive liver disease and from liver transplant recipients with confirmed

Accepted for publication 1 December 1988 cytomegalovirus infection. Necropsy liver specimens from two further patients with confirmed chronic hepatitis B virus infection were also used. Liver tissue was fixed in formalin for 18 to 24 hours and embedded in paraffin for routine histological assessment. Sections $(4-5 \mu \mathrm{m})$ were floated in warm water and mounted on slides coated with $0.1 \%$ poly-1-lysine (Sigma, UK; P-1399) in distilled water. Sections were air dried vertically at room temperature, baked at $60^{\circ} \mathrm{C}$ for two hours and stored at room temperature.

\section{PROBES}

A pHY2 1 -Y chromosome specific probe was kindly provided by Dr K A Fleming (Oxford). Biotinylated probes for hepatitis B virus (HBV) and for cytomegalovirus (CMV) were obtained from Enzo (New York, USA). Two probes for Escherichia coli genes-hygromycin $\beta$-phosphotransferase (hygro) and chloramphenicol acetyltransferase (cat) and a probe for human DNA (prepared from placenta) were kindly donated by Dr F Farzaneh (London). The three probes and pHY2.1 were labelled with biotin-11dUTP (Gibco-BRL, UK), using a nick translation kit (Gibco-BRL, UK) and were purified from unincorporated dNTPs by the spun column technique using Sephadex G50 (Pharmacia). ${ }^{7}$ The biotinylated probes were aliquoted and stored at $-20^{\circ} \mathrm{C}$.

\section{PRE-HYBRIDISATION TREATMENT}

Slides were heated at $56^{\circ} \mathrm{C}$ for $10-15$ minutes, dewaxed in xylene for 10 minutes, and twice rinsed in ethanol 
Table 1 Assessment of in situ hybridisation after digestion with pepsin $(4 \mathrm{mg} / \mathrm{ml})$ in hydrochloric acid

\begin{tabular}{llllll}
\hline & \multicolumn{3}{c}{ Molarity of hydrochloric acid } \\
\cline { 2 - 5 } & $0.01 M$ & $0.05 M$ & $0.1 M$ & $0.2 M$ \\
\hline $\begin{array}{l}\text { Non-specific } \\
\text { background staining }\end{array}$ & +++ & - & - & - \\
$\begin{array}{l}\text { Morphology } \\
\text { Specific signal }\end{array}$ & +++ & - & $+1-$ & ++ \\
\hline
\end{tabular}

for five minutes. Endogenous peroxidase activity was blocked with methanol containing $1 \%$ hydrogen peroxide for 30 minutes. Subsequently slides were hydrated through graded alcohols and washed three times in distilled water (before pepsin digestion) or in phosphate buffered saline (PBS) (before digestion with protease or proteinase $\mathbf{K})$.

Initially two pre-hybridisation protocols described for use in other tissues were used ${ }^{46}$ but these resulted in non-specific granular cytoplasmic staining in hepatocytes. A series of experiments was therefore performed using different proteolytic enzymes under varied conditions to obtain a specific hybridisation signal without non-specific staining. These included digestion with pepsin (Sigma, UK; P-6887) $4 \mathrm{mg} / \mathrm{ml}$ in 0.01 to $0.2 \mathrm{M}$ hydrochloric acid for one hour at $37^{\circ} \mathrm{C}$ (table 1); digestion with protease (type XXIV, Sigma, P-8038, $11 \mathrm{U} / \mathrm{mg}$ solid) in $50 \mathrm{mM}$ Tris-hydrochloric acid (pH 7.4) under a variety of conditions (table 2); and digestion with proteinase K (Sigma, UK; type XI, P-0390) in PBS (pH 7.4), at various concentrations (table 3). After proteolytic digestion slides were washed three times for five minutes in glycine in PBS $(2 \mathrm{mg} / \mathrm{ml})$, followed by two washes in PBS (after protease or proteinase $\mathrm{K}$ digestion), or in distilled water (after pepsin digestion), dehydrated through graded alcohols and air dried before hybridisation.

IN SITU HYBRIDISATION

A volume of $10 \mu \mathrm{l}$ of hybridisation mixture was applied to liver sections. This comprised $50 \%$ formamide (Sigma, UK), 10\% (w/v) dextran sulphate (Sigma, UK; D-6001), $2 \times$ standard saline citrate

Table 2 Assessment of in situ hybridisation after digestion with protease

\begin{tabular}{|c|c|c|c|c|c|c|c|c|}
\hline \multirow[b]{2}{*}{$\begin{array}{l}\text { Concentration } \\
(\mathrm{mg} / \mathrm{ml})\end{array}$} & \multicolumn{5}{|l|}{$37^{\circ} \mathrm{C}$} & \multicolumn{3}{|c|}{$20^{\circ} \mathrm{C}$} \\
\hline & 0.5 & 0.5 & 1.0 & 1.0 & $2 \cdot 0$ & $5 \cdot 0$ & 1.0 & 0.5 \\
\hline $\begin{array}{l}\text { Incubation time } \\
\text { (minutes) }\end{array}$ & e 15 & 30 & 30 & 60 & 60 & 10 & 30 & 15 \\
\hline $\begin{array}{l}\text { Non-specific } \\
\text { background } \\
\text { staining }\end{array}$ & ++ & $+1-$ & - & - & - & + & + & + \\
\hline $\begin{array}{l}\text { Morphology } \\
\text { Specific signal }\end{array}$ & \multicolumn{4}{|c|}{$\begin{array}{r}t++++++t- \\
-\quad+t+t+t\end{array}$} & $\overline{+}$ & \multicolumn{3}{|c|}{$\begin{array}{l}++++t+ \\
-\end{array}$} \\
\hline
\end{tabular}

(SSC), $400 \mu \mathrm{g} / \mathrm{ml}$ sheared herring sperm DNA (typeXIV, Sigma UK; D-6898), and $1.0 \mu \mathrm{g} / \mathrm{ml}$ biotinylated probe. Sections were covered with a plastic coverslip and sealed. The tissue DNA and the probes were denatured simultaneously by incubation in a hot air oven at $95^{\circ} \mathrm{C}$ for 10 minutes and then incubated at $37^{\circ} \mathrm{C}$ for 15 to 17 hours in a humidified box. After hybridisation the coverslip was removed and the slides were washed twice in $2 \times \mathrm{SSC}(\mathrm{pH} \mathrm{7.0)}$ for 10 minutes at room temperature, twice in $0.2 \times \mathrm{SSC}$ at $60^{\circ} \mathrm{C}$ for 10 minutes, once in $2 \times$ SSC at room temperature for 10 minutes and twice in PBS for 10 minutes.

\section{DETECTION OF BIOTINYLATED PROBES}

The sections were covered with $10 \%$ normal goat serum (Dako, UK) in $2 \%$ bovine serum albumin (Sigma, UK; A-7888) in PBS for 10 to 15 minutes at room temperature to block non-specific absorption. The sections were then incubated with rabbit antibiotin IgG (Enzo, USA) diluted 1/400 in PBS with $10 \%$ normal goat serum for $45-60$ minutes at $37^{\circ} \mathrm{C}$. After three washes in PBS, biotin labelled goat antirabbit antibody (Vector Laboratories, UK) was applied diluted $1 / 200$ in PBS with $1 \%$ normal goat serum for 30 minutes at $37^{\circ} \mathrm{C}$. The slides were washed three times in $50 \mathrm{mM}$ Tris-buffered saline (TBS) (pH 7.4) and further incubated for 30 minutes at $37^{\circ} \mathrm{C}$ with a preformed avidin-biotinylated peroxidase complex (ABC) $(10 \mu \mathrm{l}$ avidin, $10 \mu \mathrm{l}$ biotin labelled horse radish peroxidase in $2 \mathrm{ml}$ TBS; Vectastain ABC kit, Vector Laboratories, UK) or streptavidin-biotinylated peroxidase preformed complex (SBPC) (Amersham, UK) diluted $1 / 200$ in PBS with $1 \%$ bovine serum albumin. After three further five minute washes in TBS, peroxidase activity was shown using freshly prepared nickel-diaminobenzidine (DAB) as a substrate. Fifty microlitres of $8 \% \mathrm{NiCl}_{2}(\mathrm{BDH})$ in distilled water were added to $10 \mathrm{ml}$ TBS with $0.5 \mathrm{mg} /$ $\mathrm{ml}$ DAB and sections were incubated for five minutes followed by another five minutes with the same substrate solution plus $0.01 \%$ hydrogen peroxide. The reaction was stopped by three washes in distilled water. The staining was further enhanced by silver amplification. ${ }^{8}$ Briefly, freshly prepared silver reagent $\left(200 \mu \mathrm{l}\right.$ distilled water, $100 \mu \mathrm{l} 0.1 \mathrm{M} \mathrm{NH}_{4} \mathrm{NO}_{3}, 100 \mu \mathrm{l}$

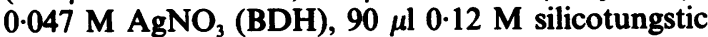
acid (Fison's UK), 7.5 $\mu$ l formalin and $500 \mu \mathrm{l} 0.47 \mathrm{M}$

Table 3 Assessment of in situ hybridisation after digestion with proteinase $K$

\begin{tabular}{lllll}
\hline Concentration $(\mu \mathrm{g} / \mathrm{ml})$ & 20 & 100 & 1000 & 1000 \\
Incubation time (minutes) & 15 & 15 & 15 & 30 \\
$\begin{array}{l}\text { Non-specific background } \\
\text { staining }\end{array}$ & ++ & +++ & + & + \\
$\begin{array}{l}\text { Morphology } \\
\text { Specific signal }\end{array}$ & +++ & +++ & +++ & +++ \\
\hline
\end{tabular}




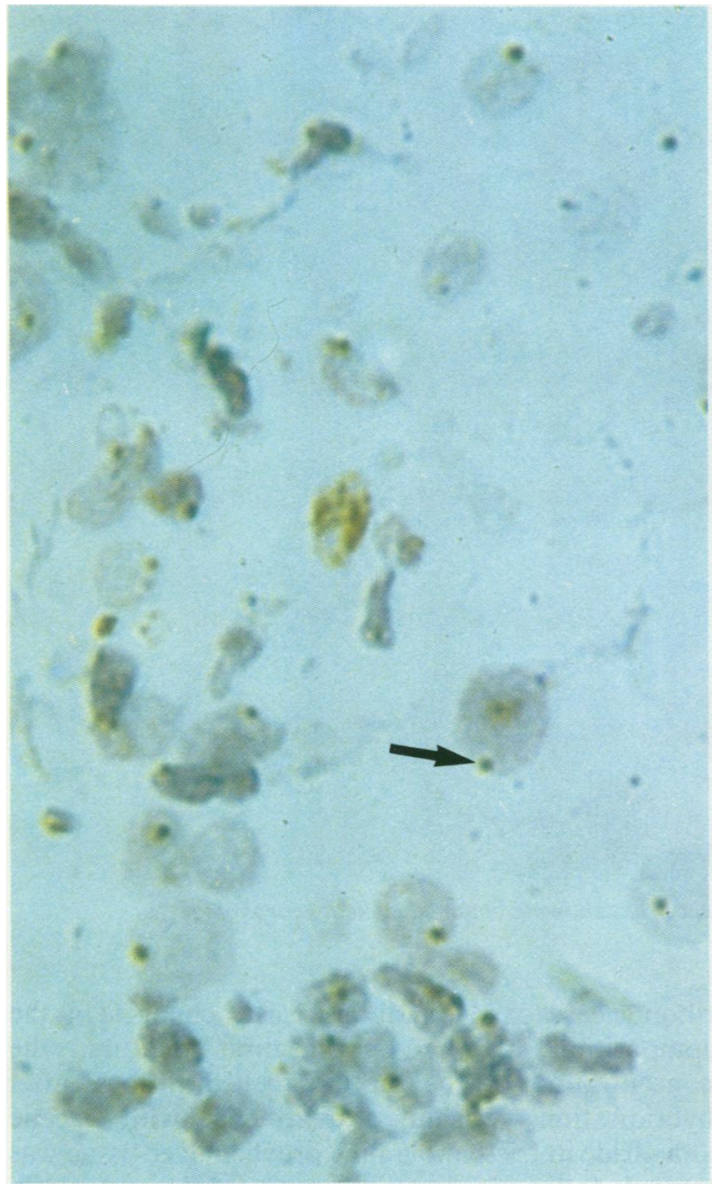

Fig 1 Hybridisation with $p H Y 2 \cdot 1$ probe on male liver tissue after digestion with protease $1.0 \mathrm{mg} / \mathrm{ml}$ for 30 minutes at $37^{\circ} \mathrm{C}$. Y body (arrowed) is seen in nuclei of both hepatocytes and lymphocytes. Cytoplasmic staining is absent.

$\mathrm{Na}_{2} \mathrm{CO}_{3}$ ) was applied to the slides for five to seven minutes at room temperature. After counterstaining with haematoxylin, slides were dehydrated, cleaned in xylene, and mounted in DPX.

\section{A VOIDANCE OF NON-SPECIFIC STAINING}

The following experiments were performed to: (i) elucidate the source of the non-specific staining in hepatocytes observed after digestions using methods described previously for other tissues-protease 0.5 $\mathrm{mg} / \mathrm{ml}^{4}$ or pepsin in $0.01 \mathrm{M}$ hydrochloric acid ${ }^{6}$; and (ii) to overcome it:

(i) 1 In situ hybridisation on non-digested liver tissue. Detection of biotinylated probes directly with $\mathrm{ABC}$ (diluted 1/100) or with SBPC (1/100) and silver enhancement.

2 Replacement of the first antibody in the detection

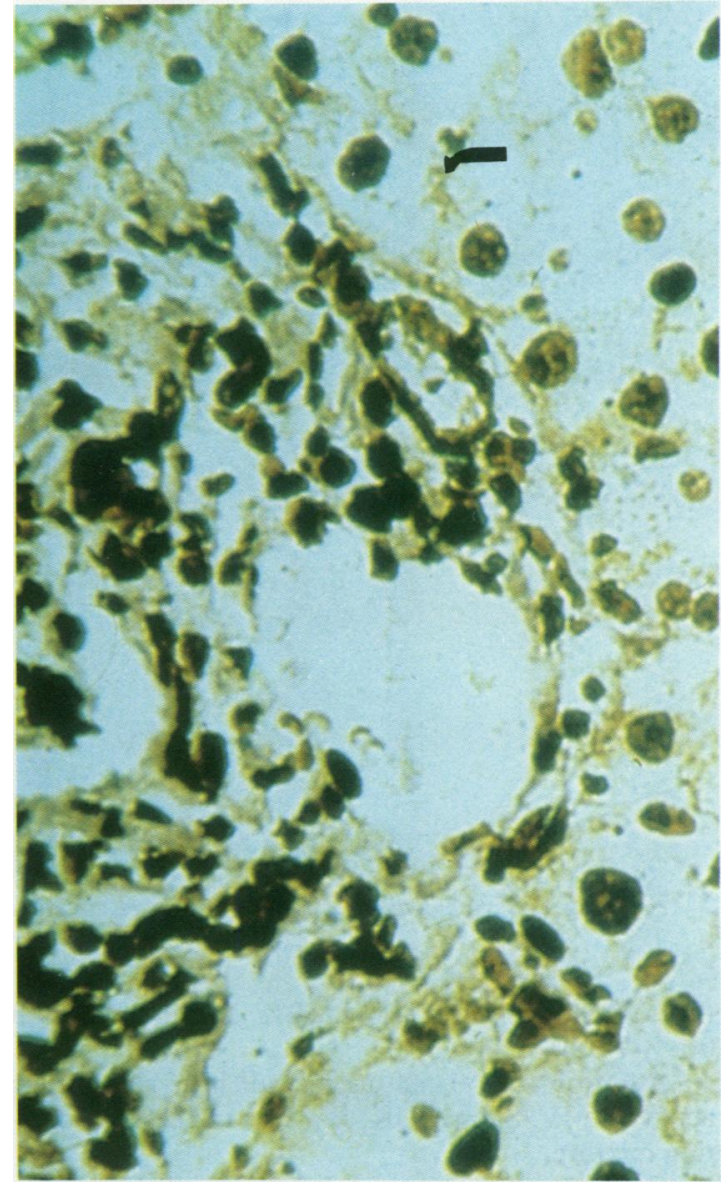

Fig 2 Liver tissue hybridised with probe for human DNA. Strong reaction is seen in every nucleus, both in parenchyma and in portal tract.

system with equally diluted rabbit antibody of another specificity.

3 Omitting rabbit anti-biotin antibody.

4 Using the same rabbit anti-biotin antibody but pre-absorbed with biotin in advance (for two hours at $37^{\circ} \mathrm{C}$ ).

(ii) 1 Pre-treatment with ribonuclease (Sigma, UK, R-5503) $100 \mu \mathrm{g} / \mathrm{ml}$ in PBS or deoxyribonuclease (type IV, Sigma, UK, D-5025) $200 \mu \mathrm{g} / \mathrm{ml}$ in $50 \mathrm{mM}$ Tris-hydrochloric acid, $7 \mathrm{mM} \mathrm{MgCl}_{2}(\mathrm{pH} \mathrm{7.5)}$ for one hour at $37^{\circ} \mathrm{C}$.

2 Addition of $5 \times$ Denhardt's solution to the hybridisation mixture $(1 \times$ Denhardt's $=0.02 \%$ polyvinyl pyrolidone, Ficoll, and bovine serum albumin (Sigma)).

3 Changes in stringency of the washes after hybridisation-varying the strength of SSC buffer, 


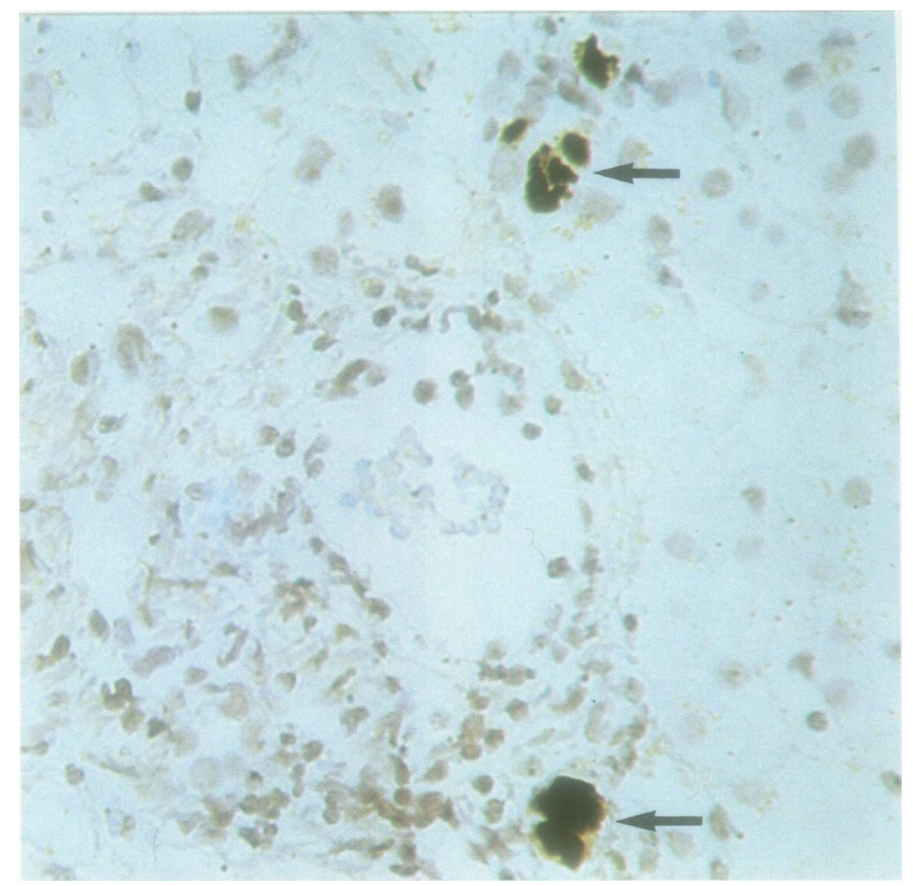

Fig 3 Cytomegalovirus DNA positive cells in portal tract areas showing changed nuclear morphology.

the temperature, or using $50 \%$ formamide with $0.1 \times$ PBS.

4 Addition of $250-500 \mu \mathrm{g} / \mathrm{ml}$ calf liver ribonucleic acid (type IV, Sigma, UK, R-7250) to the hybridisation mixture.

5 Omission of dextran sulphate from the hybridisation mixture.

6 Pre-treatment of sections with freshly prepared $0.25 \%$ acetic anhydride in triethanolamine $(0 \cdot 1 \mathrm{M}, \mathrm{pH}$ 8.0) for 10 minutes at room temperature.

7 Varying the concentration of the biotinylated probe.

8 Treatment of liver tissue follow proteolytic digestion with avidin and biotin using a blocking kit (Vector Laboratories, USA).

\section{Results}

Liver sections remained attached to poly-1-lysine coated slides after each of the digestion procedures used. Two previously published methods ${ }^{46}$ for in situ hybridisation in paraffin sections from lung, tonsil, and brain gave various degrees of granular nonspecific cytoplasmic staining without any appreciable specific signal. This staining was also present when the hybridisation mixture without probe was used on liver tissue and was not abolished by pre-treatment with ribonuclease or deoxyribonuclease, changes in the composition of the hybridisation mixture, the concentration of the biotin labelled probes, after hybridisation washing, treatment with acetic anhydride in triethanolamine or when liver tissue was treated, following digestion, with avidin and biotin before hybridisation.

The non-specific background staining was abolished and a specific hybridisation signal was shown in liver tissue by increasing the proteolytic digestion with all three enzymes used. Tables $1-3$ show a quantitative assessment of the results for in situ hybridisation obtained after digestion under a variety of conditions. Optimal results - that is, a strong positive signal for all biotin labelled probes with preservation of morphology and elimination of background staining were achieved after digestion with protease at $1.0 \mathrm{mg} / \mathrm{ml}$ for $30-35^{\prime}$ at $37^{\circ} \mathrm{C}$ (fig 1). In some liver specimens satisfactory results were also obtained following digestion with protease $0.5 \mathrm{mg} / \mathrm{ml}$ for 30 minutes at $37^{\circ} \mathrm{C}$ but at the expense of weak residual non-specific background staining in the middle of the section. Using pepsin in $0.2 \mathrm{M}$ hydrochloric acid the hybridisation reaction was strong but with loss of morphological detail when compared with protease. Using proteinase $\mathbf{K}$ a reasonable hybridisation signal was detected only after digestion at a concentration of $1.0 \mathrm{mg} / \mathrm{ml}$ for 30 minutes but there 


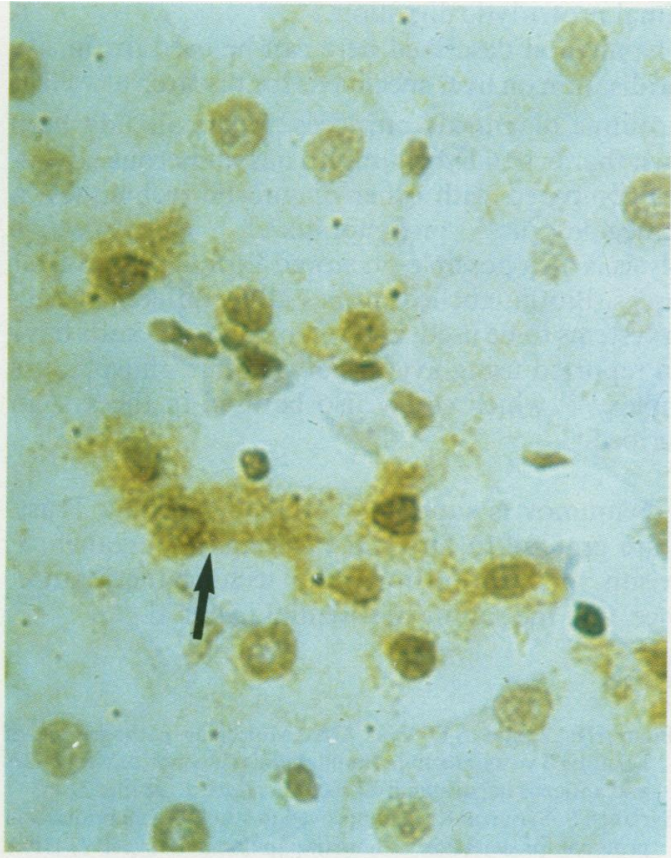

(a)

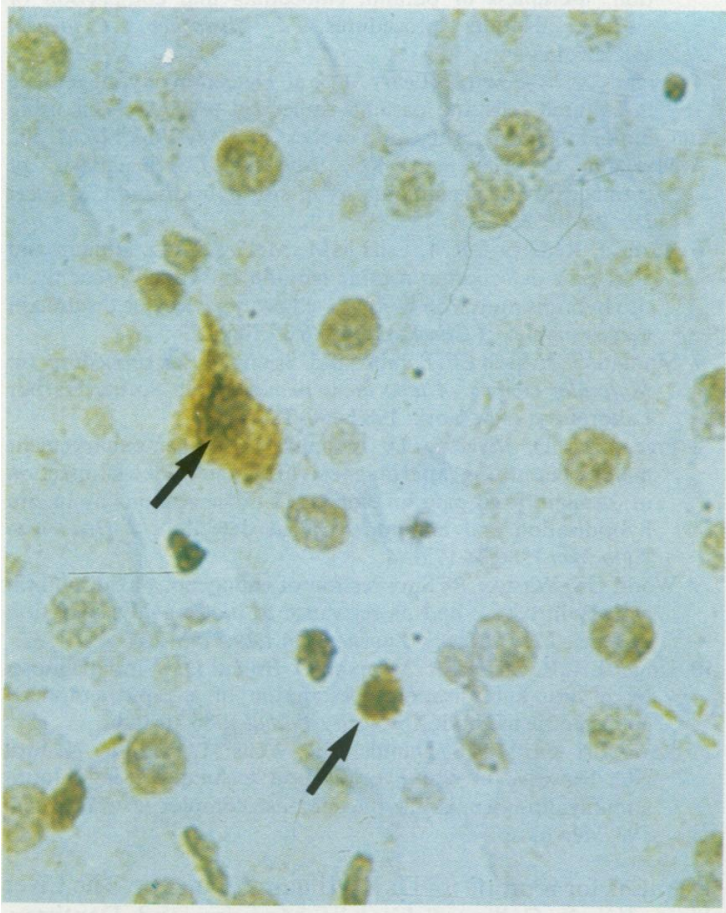

(c)

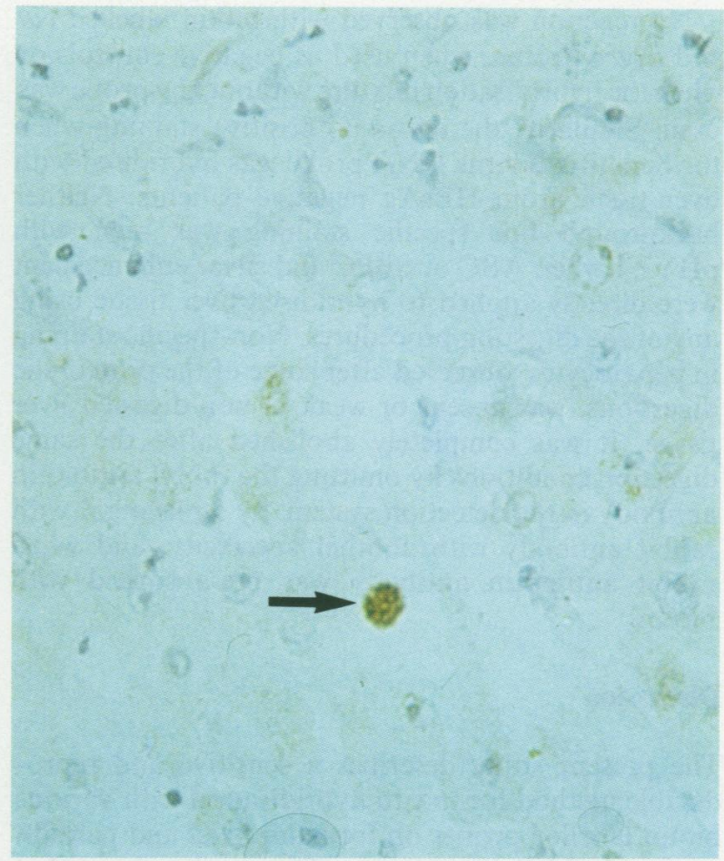

(b)

Fig 4 Liver from patient with active hepatitis $B$ virus infection hybridised with a hepatitis $B$ virus $D N A$ probe and showing various positive reactions (arrowed): (a) predominantly cytoplasmic; (b) nuclear staining; (c) nuclear and cytoplasmic staining in neighbouring cells.

was also some non-specific staining. On necropsy liver specimens slightly longer digestion was generally necessary compared with that required for needle liver biopsy specimens.

Using pHY $2 \cdot 1$ probe as a "positive control", Y bodies were visualised in almost all cells in male livers-hepatocytes, lymphocytes, bile duct epithelial cells - and were localised, as expected, predominantly at the periphery of the nuclei (fig 1). The Y body was not seen when hybridisation was performed on female livers. Similarly, as expected, human DNA probe, a further "positive control", showed a strong positive reaction in every nucleus (fig 2 ). The pattern in cytomegalovirus and hepatitis B virus positive cells was different. Cytomegalovirus DNA was detected as dense deposits, predominantly in nuclei, which were enlarged and had changed morphology (fig 3). Often, cytomegalovirus DNA was present in the cytoplasm as well and occasionally cytoplasmic staining was seen alone. Hepatitis B virus DNA staining was seen either in nuclei of normal shape and size or in the cytoplasm: of hepatocytes (figs $4 a-c$ ). 
No reaction was observed with biotin labelled cat and hygro probes, when used as negative controls or when the hybridisation mixture without any probe was used. Similarly, there was no positive staining when the hepatitis B virus DNA probe was hybridised with liver tissue from HBsAg negative patients. Neither background nor specific staining was seen with pHY2.1 when ABC or SBPC and silver enhancement were directly applied to hybridised liver tissue using any of the digestion procedures. Non-specific staining in hepatocytes, observed after some of the proteolytic digestions, was absent or weak in non-digested liver tissue. It was completely abolished after the same digestion conditions by omitting the rabbit antibiotin antibody in the detection system, by replacing it with rabbit antibody with another specificity, and when rabbit antibiotin antibody was pre-absorbed with biotin.

\section{Discussion}

The present study describes a sensitive and reproducible method for in situ hybridisation with various biotin labelled probes on formalin fixed and paraffin wax embedded liver tissue. The results show that optimal proteolytic digestion for liver varies considerably from that for other tissues. In particular, endogenous biotin causes non-specific granular cytoplasmic staining. This could be avoided with appropriate proteolytic digestion but not by changing the composition of the hybridisation mixture. Digestion is of crucial importance in unmasking DNA in formalin fixed material and in enhancing the penetration of the probe. ${ }^{4}$ Our findings show that this can be achieved with different proteolytic enzymes under appropriate conditions. This step is also critical when using radiolabelled probes for in situ hybridisation. It has been shown previously that the sensitivity for the detection of human papilloma virus-DNA in paraffin wax embedded epithelial lesions is increased by further digestion of the material. ${ }^{2}$

The observation that treating liver tissue with avidin and biotin' was ineffective in blocking endogenous biotin could be a consequence of subsequently heating the section, which may again unmask the biotin present in the liver. This notion is supported by the observation that non-specific cytoplasmic staining after digestion with pepsin in $0.01 \mathrm{~N}$ hydrochloric acid was stronger when sections were denatured at $100^{\circ} \mathrm{C}$ rather than $80^{\circ} \mathrm{C}$ (data not shown).

When direct detection of biotin labelled probes was attempted with avidin or streptavidin biotinylated peroxidase complexes it seemed to be insufficiently sensitive as endogenous biotin was not shown (nonspecific staining was completely absent); in addition, there was no specific signal for the $Y$ body, even after optimal proteolytic digestion.

The method described here can be used for in situ hybridisation on liver specimens for research as well as for routine diagnostic purposes. It has already been shown that in situ hybridisation has numerous advantages compared with other diagnostic techniques in cytomegalovirus pneumonitis. ${ }^{510}$ Retrospective analysis is also possible on stored formalin fixed liver samples. Biotin labelled probes allow different detection systems to be used, and recently good results have been reported using avidin-polyalkaline phosphatase complex, ${ }^{1011}$ which could also be used in the system described.

NV Naoumov is supported by the Wellcome Trust. We are grateful to Drs KA Fleming, F Farzaneh, F Davison, and BC Portmann for technical assistance, advice, and the supply of essential material.

\section{References}

1 Blum HE, Haase AT, Vyas GN. Molecular pathogenesis of hepatitis B virus infection: simultaneous detection of viral DNA and antigens in paraffin liver sections. Lancet 1984;ii:771-5.

2 Syrjanen S, Syrjanen K. An improved in situ DNA hybridisation protocol for detection of human papillomavirus (HPV) DNA sequences in paraffin embedded biopsies. $J$ Virol Methods 1986;14:293-304.

3 Tournier I, Bernuau D, Poliard A, Schoevaert D, Feldmann G Detection of albumin mRNAs in rat liver by in situ hybridisation: usefulness of paraffin embedding and comparison of various fixation procedures. $J$ Histochem Cytochem 1987;35:453-9.

4 Brigati DJ, Myerson D, Leary JJ. et al. Detection of viral genome in cultured cells and paraffin embedded tissue sections using biotin labelled hybridisation probes. Virology 1983;126:32-50.

5 Myerson D, Hackman RC, Meyers JD. Diagnosis of cytomegaloviral pneumonia by in situ hybridisation. $J$ Infect Dis 1984;150:272-7.

6 Burns J, Redfern DRM, Esiri MM, McGee JO'D. Human and viral gene detection in routine paraffin embedded tissue by in situ hybridisation with biotinylated probes: viral localisation in herpes simplex. J Clin Pathol 1986;39:1066-73.

7 Maniatis T, Fritsch EF, Sambrook J. Spun-column procedure. In: Molecular cloning. A laboratory manual. Cold Spring Harbor Laboratory, New York: 1982:466-7.

8 Przepiorka D, Myerson D. A single step silver enhancement method permitting rapid diagnosis of cytomegalovirus infection in formalin fixed paraffin embedded tissue sections by in situ hybridisation and immunperoxidase detection. $J$ Histochem Cytochem 1986;34:1731-4.

9 Wood GS, Warnke R. Suppression of endogenous avidin-biotin activity in tissues and its relevance to biotin-avidin detection systems. J Histochem Ctytochem 1981;29:1196-204.

10 Unger ER, Budgeon LR, Myerson D, Brigati DJ. Viral diagnosis by in situ hybridisation. Description of a rapid simplified colorimetric method. Am J Surg Pathol 1986;10:1-8.

11 Lewis FA, Griffiths S, Dunnicliff R, Wells M, Dudding N, Bird CC. Sensitive in situ hybridisation technique using biotinstreptavidin-polyalkaline phosphatase complex. J Clin Pathol 1987;40:163-6.

Requests for reprints to: $\mathbf{D r}, \mathbf{R}$ Williams, Director, The Liver Unit, King's College School of Medicine and Dentistry, Denmark Hill, London SE5 8RX, England. 